with ardour at his special subject, made arrangements for extensive mosquito surveys, and collected a large amount of material. His tragic and untimely death has robbed the School of a zealous and well-trained research worker, and is greatly deplored by all who knew him.

\section{Mr. A. R. McCulloch.}

By the death of Allan Riverstone McCulloch, which took place at Honolulu on September I, I925, systematic ichthyology lost one of its foremost exponents. He was born at Sydney, New South Wales, on June 20, I885, and at the early age of thirteen he commenced work at the Australian Museum, Sydney, as an unpaid assistant. Even in those early days young McCulloch was distinguished by his enthusiasm, his ability, and his determination to succeed. Assisted and encouraged by Mr. Edgar R. Waite, then in charge of the vertebrate section of the Australian Museum, he made rapid progress both in the study of zoology and in drawing, and when, in 1906, Waite became Curator of the Canterbury Museum, New Zealand, McCulloch succeeded him, though he was then not quite twenty-one years old. By that time he had definitely resolved to devote himself to the study of fishes, and that became his life-work, though he was skilled in all branches of zoology, and was a recognised authority on decapod crustacea.

Exceedingly versatile, McCulloch was never satisfied with the second best, and became an expert photographer and kinematographer, an accomplished artist and musician, and a delightful lecturer. Although not of robust physique he was active and full of courage, and had made several adventurous trips to the Great Barrier Reef and various Pacific Islands. In I922, in company with Captain Frank Hurley, he traversed part of Papua, and returned with many valuable specimens and a wealth of observations on the natives and the animals of the island.

At the time of his death, McCulloch was on long leave granted him by the Trustees of the Australian Museum in the hope that his bodily and mental vigour would be restored. He left Australia to attend the Pan-Pacific Fisheries Conference at Honolulu, and, with his accustomed ardour, he took a leading part in the work; but he overworked himself and paid the penalty of enthusiasm in his chosen field of research.

When McCulloch died at the early age of forty years, he left behind a record of accomplishment rarely equalled in the full span of a human life. His work was marked by thoroughness and accuracy. Largely as a result of his numerous contributions, the taxonomy of Australian fishes has been placed on a secure foundation. Most of his work appeared in the Records of the Australian Museum or in the official publications of other State Museums in Australia. His most important work, which embodied the results of many years' toil and research, was his "Check List of the Fishes and Fish-like Animals of New South Wales," published by the Royal Zoological Society of New South Wales (Australian Zoologist, vol. I, rgr9, pp. 2 I7-227; vol. 2 , I92I, pp. 24-68; I922, pp. 86-I30). This fine piece of work was in 1922 issued separately as "Australian Zoological Handbook, No. I," and forms an enduring monument to the industry and ability of the author.

McCulloch had a most pleasing personality, and was ever ready to assist his colleagues. Many scientific workers, both in Australia and abroad, owed much to his helpful advice and criticism.

C. A.

\section{Mr. E. K. JORDAN.}

ERIC KNIGHT JORDAN, one of the most active and promising among the younger geologists of America, was killed in an automobile accident on March ro. Born in San Francisco on September 27, 1903, the son of David Starr Jordan and Jessie Knight Jordan, he had shown in early boyhood unusual interest in scientific research. Before he entered the university he had made a collection and prepared a manual of the molluscs of California. This MSS., still unpublished, contains much original work, especially on the chitons and the minute snails, Odostomia. His study of the molluscan fauna of Trinidad Head (Calif.) was written when he was fifteen years old, and was published by the U.S. National Museum.

Graduating from Stanford in I923, with geology as his major subject and zoology as a minor, Jordan made in 1924 , under the auspices of Cornell University, a large collection of fishes from Hawaii. Under the direction of the California Academy of Sciences, he took part in a biological and geological survey of the middle portion of Lower California. The reports on the last two expeditions are still unpublished.

A unique combination of heredity and environment made Eric Jordan a perfect specimen of young manhood. Handsome, vigorous, earnest, with a love for his chosen field of science which might be said to approach genius, he was heir also to the personal charm which has endeared his parents to numberless Stanford men and women. But a short month before his death he was married to an accomplished class-mate of his, Elizabeth Roper. The scientific world can but tender its respectful sympathy to one of its masters, so tragically bereaved, and mourn for so fair a promise, never to be fulfilled.

Albert Guérard.

WE regret to announce the following deaths:

Dr. S. M. Barton, professor of pure mathematics in the University of the South, and a charter member and past president of the Tennessee Academy of Sciences, on January 5, aged sixty-six years.

Prof. L. G. Gouy, of the University of Lyons, distinguished for his contributions to the theory of the propagation of spherical waves, the velocity of light and Brownian movements, on January 27, aged seventy-two years.

Prof. W. J. Lewis, F.R.S., senior Fellow of Oriel College, Oxford, and professor of mineralogy in the University of Cambridge, on April 16, aged seventynine years.

Dr. Carlo de Marchesetti, honorary director of the Museo Civico de Storia Naturale and director of the botanic garden, Trieste, on April 2.

$\mathrm{Mr} H$. Kirke Swann, author of a number of important ornithological works, including a "Monograph of British Accipitres," now in course of publication, on April I4.

NO. 2947, VOL. I 7 ] 